\title{
Practices and Challenges of EFL Teachers in Monitoring Learners' Group Performances and Administrating Feedback with Reference to High Schools in Nekemte, Ethiopia
}

\author{
Zeleke Teshome Lucha*
}

Institute of Language Studies and Journalism, Wollega University, P.O. Box No: 395, Nekemte Ethiopia

\begin{abstract}
The purpose of this study was to find out how teachers of EFL monitor their students' group performances and handle feedback provisions in secondary school English classes with particularly reference to grade 10. To gather information, two instruments (classroom observation and interview) were employed. The study is made on twelve subjects: four EFL teachers and eight students at Biftu Nekemte and Dergie High schools in east Wollega Zone Nekemte Town. The teachers were selected by their respective department heads and the students on the basis of their first semester achievements. Accordingly, eight classroom observations and eight students (four from each school and those being taught by the observed teachers) were interviewed. The result of the study showed that EFL teachers do not pay significant attention for their students' understanding responsibilities participating in group work. Setting group work according to students' interest and ability has not become practical by the majority of the teachers as they form groups only on desk basis. Assigning only few active students has been found discouraging for the majority since few clever students dominated students' group performance. The finding revealed that students were observed frequently using their mother tongue than English during group discussions. What is more, although some teachers move around the class room, others merely stand in front of the class. Teachers do not manage feedback provision in the context of full class after group work in general and the language and content of their discussion in particular since they give little attention for students to comment each other. Based on the findings, it was concluded that EFL teachers' group work monitoring skills and feedback provisions become relatively fragile as many of the students do not get opportunities of practicing the target language. Therefore, the importance of change on EFL teachers' ways of administrating of group work with the help of the concerned bodies was recommended.
\end{abstract}

Article Information

Article History:

Received : 15-01-2015

Revised : 16-03-2015

Accepted : 19-03-2015

Keywords:

Practices

Challenges

Monitor

Group management

Group Performance

Feedback

*Corresponding Author:

Zeleke Teshome Lucha

E-mail:

tzeleke11@yahoo.com Copyright@2015 STAR Journal, Wollega University. All Rights Reserved.

\section{INTRODUCTION}

English is taught in Ethiopia as a subject starting from elementary level of education. In secondary schools and tertiary level, success and / or failure in academic matter entirely depends on success and /or failure in using English. It is also a medium of instruction for the country, which is used for international communication and business. This indicates the significant roles that English plays in Ethiopia ingeneral and schools in perticular.

Though some changes of curricula and methods of English Language Teaching (ELT) have been made in the past decades, when most Ethiopian students proceed to senior secondary and preparatory schools as well as pass the ESLCE and join colleges and universities, their level of performance in using English in a meaningful way seems to have not been provided with various opportunities of using English. One of the likely reasons for this is the methodology that is being used, a decline in the motivation of the learners and other factors have significantly affected the achievement of the learners.
In an attempt to help students use the target language in various contexts communicatively, Hill proposed the application of a new approach and suggested that language teachers' methods of teachings. To this effect, group work is one process of organizing a class in which many students could actively participate. According to Hill (1995), group work is one of the most important way in which foreign language learners would exercise using the language in a meaningful way.

\section{EFL Teachers Roles in Group Monitoring}

Basically, the roles of EFL teachers' in small- group teaching are different from those in the whole-class set up. That is to say, a teacher is no longer a lecturer or transmitter of knowledge and material, but rather a facilitator of learning who focuses on the learning process by encouraging cooperation among the learners during group activities. With regards to the change of teachers roles in the learning process Murdoch (1990:16) explains: 


\section{Zeleke Teshome Lucha}

The perception of the role of the teacher in the learning process has radically altered. The teacher is no longer expected to tightly orchestrate and dominate all works in the class room. Formerly, his role was seen mainly in terms of providing system, and then closely controlling practice of these models.

\section{EFL Teacher as an Organizer}

In the learning -teaching process of today's language classes, the teacher has a significant role of planning a lesson and creating favorable situations for the students. With regards to this, the EFL teacher should introduce an activity into the classroom that best suits the learners' interests. Here, the reason of their discussions and the goals of the group work should be made clearer for the learners. Thus, the teacher should make sure that the learners know what they have to do by going, for example, over directions carefully, and giving students time to ask any question they may have.

\section{EFL Teacher as a Motivator}

It is widely believed that motivation is the key concept to learn foreign language as it can create conducive classroom atmosphere. Unless there is a productive classroom atmosphere, learners will hardly be motivated to involve or participate in any activity. Research indicates that learning under stress and negative attitude is often ineffective and can even be a negative valve. To create the best possible group work environment of language skills to develop, according to Byrne (1987), teacher's ability to motivate the learners, to arouse their interest and involve them in group discussion would be vital. In considering the role of EFL teacher as a motivator, some scholars (for example, Hadfield, 1992, Nunan and Lamb, 1996, and Christison, 1994:142) explain:

- Teachers should establish aclimate of trust among the members of the group, so that they can feel confident enough to say and do tasks in front of others.

- Teachers should look at tasks that meet students' abilities and interests; and

- Teachers should praise and prove positive reinforcement to promote group success.

Therefore, if EFL teacher is to perform well and the students use the language well, the teacher should motivate them that each learner should have a part on the work. Here as a motivator, the teacher should prepare an activity which by itself make learners say something having a share.

\section{EFL Teacher as a Resource Person}

In using group work as a method of teaching a language, the teacher should also take the role of the resource person while the students are working. Along this line of thought, Wheeler (1994: online) points out the things a teacher should do while his /her learners are working in groups. Some of the things include making sure that all the learners understand and are participating in the group activity, giving assistances when needed, making on the spot error-corrections when communication among the group member is hampered, and making notes on errors that can be discussed after the activity.

It is important to monitor group work while it is in progress. The challenge for the teacher is to assure equal participation from all group members. Here, the teacher is expected to make sure that there is no abuse or ridicule
Sci. Technol. Arts Res. J., Jan-March 2015, 4(1): 187-196

taking place within the group. For example, Taylor (1998:94) indicates that a good student- teacher relationships means a learner knows he/she can turn to the teacher for advise, support, encouragement and/or confidence boosting. When the students work in groups, the teacher has to move from groups- to-groups, inspecting whether the learners are performing well and whether they need help. Harmer (1991:242) discusses the role of the teacher as a resource person as:

--- the teacher should always be ready to offer help if it is needed. After all we have the language that the students may be missing, and this is especially true if the students are involved in some kind of writing task. Thus we make ourselves available so that students can consult us when they wish.

As explained above, while students are doing their group work, the teacher should circulate to listen and give help where needed. This should be executed fairly by the teacher. The reason for this is that students who are neglected might lose interest on the task as they feel the teacher has lost interest on them.

As the students are doing group work activities, with all the modern emphasis on communication, the teacher is free from his/her traditional role of instructor, corrector and controller. At the center of this fact is the belief that she/he wonders round the class giving help where needed, caring about slow students' process in their handling of the communication skills in their group, the teacher should not hover over and interrupt them. This is to allow free use of the target language. Gower and Walters take up this idea and suggest: "Occasionally, students will want you to help them say correctly but don't hover so close to any group that they get self conscious and frightened of making mistakes. If you do have to get involved to it discretely, do by crouching at the level of the group and talk to them" (Gower and Walters, 1983:46).

Still, while the group activities are in progress, on the part of the teacher as a resource provider, follow up and discussion of an activity are vital in order to help them feel that they are working purposefully. The teacher should, in such setting, move around the class to find out how the learners are getting on to provide them assistance, where they need. In support of this idea, Brumfit (1984:74) discusses, "Part of the teacher's task may be to monitor group performance by being ready to introduce appropriate remedial activity during group work". In this framework, monitoring what learners are performing is just a valuable skill as teaching.

With regards to the general role of the teacher as a resource, Littlewood (1981:70) lists:

- As general oversees of his students' learning, he/she must aim to coordinate the activities so that they form a coherent progression, learning towards communicative ability.

- As CR manager, he/she is responsible for grouping activities into lesson and for ensuring that these satisfactorily organized at the practical level.

- In others, he/she will not intervene after initiating the proceeding, but will let learning takes place through independent activity.

- While such independent activity is in progress, he/she may act as a consultant or an advisor, helping where necessary, the strengths and weakness of the classroom. 
As explained earlier, therefore, the teacher has to pay the face-lifting role by monitoring what is going on in the $\mathrm{CR}$ and listen to the students' views and criticisms and then adapt to the perceived needs of group performances.

\section{Organization of Group Performances}

One of the ways of providing the learners more of the time they need to practice the language "...is by dividing the class into pairs or groups" (Gower and Walters, 1983:41). In here, the description of group work elements, procedure, roles and outcomes are presented. A model by Ur (1996:234) is slightly modified and used in this area. In her model of group work organization, she forwards presentation, processes during the practice, providing closure and feed back so as to achieve success. Here the researcher is concerned with outlining these steps used in-group work organization by deliberately consolidating the above points since the main target of the paper is to find out how EFL teachers monitor group work performances and handle feedback provision. In this section, how the teacher introduces the lesson, the decisions to be made during the presentation stage like group size, assigning students to groups, group duration, classroom arrangement and role assignment are discussed.

\section{Introducing the Lesson}

This is the stage where the teacher introduces the new material and challenges the learners try out and explore new ideas. Harmer describes the idea of introducing the lesson as, "this is where (the teacher) explains exactly what the students should do. He may tell the students they are going to do in pairs ..." (1983:203). In this role of facilitator, the teacher should begin his lesson by briefing students on the activity they will be performing. Ur (1996:234) consolidates the value of clear instruction in introducing the lesson. She explains, "...the instructions that are given at the beginning are crucial, if the students do not understand exactly what they have to do, they get confused." This is what the teacher should do in relation to the effects of clear instruction in which students can help and learn from each other if they are clear with the instruction, language, tasks and the expected roles. What Wright has stated concerning lesson introduction might give us an insight of clear instruction before embarking on learning tasks (Wright, 1987:70). In this way, teachers should clarify that knowledge as a prelude to embarking on new knowledge.

At the beginning of the lesson, thus teachers should give attention to ensure that all the group members are clear about tasks to be performed, procedures, and routines. In fact, these are responsibilities the teacher should do prior to plunging students to group activities or teaching a lesson. Moreover, Borich (1988) and Lewis and Hill (1987) emphasize CR instruction and explanations should be simple, precise and explicit to avoid boredom and confusion. Without clear instruction, learners might hardly know what to do and grasp what comes after.

\section{Preliminary Rehearsal}

Taking the level of the students into consideration, the teacher should provide students a preliminary grasp of the language they are expected to practice in the given situations. According to Ur (1996), learners should be expected of how to do the tasks. This is based on the fact that without the necessary language that fosters their interaction among each other, learners would be handicapped to cooperate. On this issue, Norman et. al (1986) point out...it is better to take one language item rather than too much language at once.

\section{Decision during Presentation}

Under this sub-section, issues of group size, how student-learning groups can be formed with its duration, physical nature of the CR, the assignment of student to group activities and related points are presented.

\section{The Size of the Group}

Research indicates that the smaller each group members will be a chance that at least one participant will assume the role of passivity -who lets the others do all the works where decisions have to be made no matter how well designed a communicative activity is. If there are too many students in each group, lots of them depend on the activities being done by few.

In support of this idea, Norman et al. (1986:12) suggest, "The choice of group size for language practice actively will depend largely on the size of the class and the aim and the type of activity in question". The teacher should remember that the important thing is for the learner not to forget the fact that the expanded group he/ she has, the harder it will be for her/ him to keep an eye on them. Concerning group size and its ground they further extend:

Remember that a shift from individual to group learning is a process, not a single event. Students need time to adjust to it.... Start with the smallest group size (pair work) and then expand the groups to more members. Four is probably the best number with younger students. The group size will depend also on the type of the task (Norman et.al, 1986:75).

From this statement, it seems fair to deduce that the size of the group should be decided on the basis of the task type, learners' experiences and the time given for the effectiveness of group work. With respect to this issue, different scholars have different point of view. For example, Brumfit, 1984:71) puts the range of group size from 3-15 persons, whereas Girma (2003:105) citing different sources reduces it to 2-5 or 6 students.

As stated earlier, the teacher should form the right group size for the right group activity. This is to mean, a limited activity with straight forward purposes will probably require pairs or small groups. But Byrne (1987:75), and Gower and Walters (1983: 43) underline that if the teacher wants his/her students share more ideas and have more time, a larger number may be better.

\section{Assigning Students to Groups}

How learner group should be formed is the other important aspect of CR organization. It is practically difficult for ELT teachers to assign students to groups due to the differences that exist among the learners. Some teachers form groups based on the students general ability, random, age, achievement, friendship, purpose and type of the task and, others form on the basis of learners' interest or specific skill (Callahan and Clark, 1988, Johnson and Johson, 1990). But, Amends (1997:125) argues, "this task will vary according to the goals teachers have for a particular lesson and...the ability levels of students within their classes". Thus, with regards to assigning learners to group, it seems unfair 
and ineffective to go either in line of learners' general ability or particular skills or interests. It is a good idea to make groups of strong and weaker learners and much is expected from the ELT teachers to consider the particular situation they are involved in and the types of activities students are engaged in.

\section{Classroom Arrangement}

While conducting group work, CR setting is a vital factor reflecting a number of relevant features of the teaching -learning situation. Here, factors such as whether the desks are fixed or easily moved and the student population in the CR might be significant considerations when planning group works. To this effect, EFL teacher should give special attention for students' sitting arrangements which go with the activities they are going to be engaged in. With regards to this point, Gower and Walters (1983:33) state, "how the seats are arranged depends on the size of the class, the size of the groups, the type of activity and the style of the furniture".

It should be noted that the teacher does not always need to be at the front of the class. In other words, she/ he is highly expected to try out sitting arrangements that allow the whole class to be the focus. Here, the seating suggests the removal of the teacher from his/her dominant role during certain activities. In relation to the effects of seating arrangements while conducting group activities, Littlewood (1981:47) says:

The dangers of excessive teacher domination may often be reduced by introducing more informal seating arrangements. A more informal layout, for example, in a circle, can help greatly to rein for the learners' equality as communicators. The teacher may also decide to divide a class into independent groups, as in the problem solving activities.

In addition, changing learners' sitting arrangements can help them interact with different individuals, which at the same time changes the focus from the teacher. If there is no physical restriction on the possibilities like room size and the nature of the CR furniture (such as tables, benches, desks), it allows a range of various situations to be interacted within the classroom.

As foreign language teachers, we need our students form groups and discuss using English in the activities. They, to use the language as natural as possible, should sit close enough to each other, which helps them to use the materials together and then talk to each other with little difficulty. Furthermore, such sitting arrangement can reduce the noise that may disturb other groups and /or the neighboring room during the discussion.

In support of this idea, Lewis and Hill (1985:40) forward:

The spoken language is about people talking to each other. If students are sitting in straight lines facing the back of each other's necks, this is not easy to do! You should be prepared to re-arrange the desks for your language lessons.... So that it is both easier and more natural for students to see and talk to each other.

For a school class of perhaps $70-80$ students, like the Ethiopian school where the chairs are fixed to the desks, Nolasco and Arthur (1986:83) forward a solution stating, "where it is impossible to move the chairs at all because they are fixed to the desks, communication can be facilitated by asking students to turn round to face the person behind them". Thus, considering that CR furniture can affect the learning atmosphere to some extent, the teacher should implement what is best with the existing furniture.

\section{Role Assignment}

As a technique of communicative language teaching in group work, learners' active involvement is expected. In assigning his/her students to group activities, a teacher would be on a far more influential scale than with traditional methods. But the reason that the focus of learning has moved to the learner, many people are afraid that teachers will have a much smaller role in the classroom. But according to Tudor (1996:230), the learner-centered classroom requires continuing hard work for the teacher in assigning responsibility for his/her students. The performance of each group members depends to a great extent on the strength of each individual's contribution. In the concept of group activity, each learner has his/her own role. As an individual learner role, Wright (1987:117) notes:

\section{Despite the tendency towards establishing group} norms of behavior in the classroom, every learner remains an individual; No learning group is every totally homogenous except in cases of shared culture or roughly compatible age ranges. Even within such a group there is likely to be a series of differences between the individual learners.

\section{Process during the Practice}

The aim of conducting group work in EFT is that students can profit by discussing their ideas with their fellows. It goes without saying that group work helps to develop important social virtues among the members of individual group if the teacher takes the opportunity for learners' language practice and uses it for much of the lesson time. During the process of group work, the role of the teacher could be that of an observer and facilitator. Effective group performance is dependent on running smoothly and effectively where teachers must monitor the group interaction strongly and provide assistance when asked. Arends (1997:145) stresses this fact that when the teacher inspects moving, the students will also go cooperatively and at ease.

During this process, the teacher should offer advice for students or provide the necessary language items, encourage them to participate, make suggestions concerning how they may proceed in an activity and the like. On the whole, the teacher should monitor group interaction to check if students have understood his/her instructions, to assess how well they are performing the task given cooperatively and to evaluate particular language strengths and weaknesses for later learning (Harmer, 1991; Littlewood, 1981; Moore, 1995, and Gower et.al, 1995).

Therefore, the job of the teacher during the group performance is to go from group to group, monitor group dynamic and either contribute or keep out of the way, whichever is likely to be mere helpful.

\section{Providing Closure}

At this moment, the teacher asks the group leaders, or voluntary students or a group that can model the class to present or report what they have accomplished in their 


\section{Zeleke Teshome Lucha}

groups. It could be something written or reported orally. This depends on the teacher's time budget. That is to say, if the teacher has set a time limit and informs the students the duration of their discussions, this will help him/her draw the activity to an end at a certain point. Ur (1996:234) points out, "Try to finish the activity while the students are still enjoying it and interested, or only just beginning to flag".

\section{Providing Feedback}

Feedback provides reinforcement for things the students did well and suggestions for the things that might have been done better. For each end of group or lesson discussion, the teacher should provide a feedback that integrates the various perspectives represented within the students' responses. Feedback is given to students to summarize the responses and reports from different groups. In providing feedback, the teacher should also call attention to inappropriate responses or reports without naming the offenders and the encouragement of the high quality responses or reports. With regards to feedback provision, Ur (1996:234) notes, “...it usually takes place in the context of full-class interaction after the end of the group work". The teacher should take the opportunity of a feedback session for the students to comment and judge their own performances in the cooperative manner. In other words, it should be information that is given to the learner or group members about his or her performance.

The focus of the teacher's feedback should not simply be on how well or badly the groups have performed. It should be related to the content of the group task and the linguistic performance of the learners. This kind of feedback, according to Biota and Ease (1994:208), help "to maintain and enhance the collective as well as individual self-esteem of students". Besides, it helps learners to understand the value of discussing in groups cooperatively. In providing feedback, information about the content of the work and the learning events is treated if the teacher is in a position to create a cooperative atmosphere (Nunan and Lamb, 1996).

In the context of language learning, providing feedback on the performances of the learners may take many forms. Ur (1996:234) points out that giving the right solution, listening to and evaluating suggestions, pooling ideas on the board, displaying materials the groups have produced and the like can be used to express appreciation of the effort that has been invested by the groups.

As the general objective of this study is to investigate how language teachers monitor group performances and handle feedback provisions in grade ten EFL classrooms found in east Wollega zone, the researcher thinks that
Sci. Technol. Arts Res. J., Jan-March 2015, 4(1): 187-196

language learning may be highly influenced by the method and technique the teachers employ in the classroom. By taking group performance monitoring and feedback provision as fundamental factors for students' language improvement, this study attempte to answer the following questions:

1. How do language teachers monitor group performances?

2. How do they provide feedback?

\section{MATERIALS AND METHODS}

This study was aimed at investigating the practices and challenges of EFL teachers in monitoring learners' group performances and administrating feedback with particular reference to two high schools in Nekemte town. For this purpose, thus, a descriptive research method i.e. the broad domain of qualitative methodology was used to explore the perceptions of the informants (Burgess 1983).

\section{Respondents and Schools}

Among 16 high schools found in East Wollege Zone, two schools found at Nekemte town were deliberately selected for the study as the researcher knows the area very well and there might not be significant difference among government high schools concerning textbooks and methods they are using. The schools were Biftu Nekemte and Dergie high schools. The subjects were grade 10 English teachers (hereafter termed T1, T2, T3 and T4) and their students (hereafter termed S1, S2, S3, S4, S5, S6, S7 and S8). Based on this, a total of four teachers (two from each school) and eight students (four from each school) were selected for the study. The teachers were purposively chosen by English department heads of the schools considering that there were teachers who might not be voluntary to be observed and to give interview information, as they would not treat such things.

With regards to the selection of students, first the selected English teachers assigned the classes to be taken for the study. Once the sections had been chosen, the next step was to identify eight (8) students who would be closely interviewed. The researcher set a criterion for the section: their 1st semester English result. Therefore, the researcher was looking for top-ranking, average ranking and bottom-ranking students from each school as far as their English result was concerned. High, average and low category was used to select students for this purpose. To do this, English teachers and homeroom teachers of the sections were involved.

Below, there are two tables that show the sources of the data and other information about the population and selection.

Table 1: Information about Teacher -Respondents

\begin{tabular}{cccccccc}
\hline School name & $\begin{array}{c}\text { Number of } \\
\text { Grade 10 teachers }\end{array}$ & Interviewees & $\begin{array}{c}\text { Sections } \\
\text { observed }\end{array}$ & $\begin{array}{c}\text { Teachers } \\
\text { observed }\end{array}$ & \multicolumn{2}{c}{ Observed and Interviewed teachers } \\
\hline Biftu Nekemte & 5 & 2 & 2 & 2 & 14 and 30 & Both B.A in English. \\
\hline
\end{tabular}

Table 2: Information about Student Respondents

\begin{tabular}{|c|c|c|c|c|c|c|}
\hline \multirow{2}{*}{$\begin{array}{l}\text { School } \\
\text { Name }\end{array}$} & \multirow{2}{*}{$\begin{array}{c}\text { Number of } \\
\text { sections in G. } 10\end{array}$} & \multirow{2}{*}{$\begin{array}{l}\text { No of Students in } \\
\text { observed Classes }\end{array}$} & \multicolumn{3}{|c|}{ Interviewees' achievement } & \multirow{2}{*}{$\begin{array}{c}\text { No of students } \\
\text { During Observation }\end{array}$} \\
\hline & & & High & Average & Low & \\
\hline Dergie & 6 & 84 & 1 & 2 & 1 & 71 \\
\hline Biftu & 5 & 76 & 1 & 2 & 1 & 69 \\
\hline
\end{tabular}




\section{Zeleke Teshome Lucha}

High achievers -students who are categorized as best students of the school whose average is above 80 based on the first semester result. However, the results are different depending on the schools and students. Low achievers-students whose averages are below 50 and failed with more than one subject according to the first semester result.

\section{Instruments}

In order to describe the practices and challenges of EFL teachers in monitoring learners' group performances and administrating feedback in their classrooms, the data were compiled using two research instruments: interview and classroom observation. In order to get the teachers to be observed, the researcher consulted the school directors and then the English department heads. The researcher along with the English department heads in the two schools selected the classes to be observed. To do the observation, the researcher arranged the date and the sections by contacting the teachers and explaining for lesson observation. Observation of each section was carried -out twice with the help of video recordings in which the first one was done to familiarize the researcher with the classroom. In other words, the first observation was a pilot study used as a lesson to learn for the main observation which was an opportunity to experiment with the observational techniques of students' group performances.

Four lessons taught by four teachers were observed during the actual observation time. To gather information, observation checklist was adapted from Wajnryb $(1992: 111)$ and also derived from the existing ELT literature on monitoring group performances.
Sci. Technol. Arts Res. J., Jan-March 2015, 4(1): 187-196

Therefore, to get further information which could validate the data collected through classroom observation, semi-structured interview was used with teachers and students after the observations were completed. A total of four teachers (the observed ones) and eight students (those being taught by the four teachers) were included in the interview.

\section{Method of Data Analysis}

The data obtained from EFL classroom observations and semi-structured interviews were organized by replaying and watching video recordings and then grouping answers together across respondents. The data attained via the instruments were analyzed qualitatively using the backups of related literature, observation checklist and interview protocols.

\section{RESULTS AND DISCUSSION}

Under these headings, the data collected through CR observation and interview were presented and discussed after categorizing them according to their relationships and importance to the point of discussion.

As mentioned earlier, the goal of this study was to found out how teachers monitor group performances and handle feedback provision in EFL classroom at secondary school level. To this effect, the researcher adapted the observation checklist from Warring (1992:111) and the existing EFL literature to see how teachers treat group work. Thus, the table below presents a summary of the findings of how teachers moved in to group performance during the observation in the EFL classes.

Table 3: How EFL teachers move into group performence during CR observation session

\begin{tabular}{|c|c|c|c|c|c|}
\hline \multirow{2}{*}{ Teacher Roles } & \multirow{2}{*}{ Sub-skills } & \multicolumn{4}{|c|}{ Teachers observed } \\
\hline & & $\mathrm{T} 1$ & T2 & T3 & T4 \\
\hline \multirow{8}{*}{$\begin{array}{l}\text { Moving in to } \\
\text { group activity }\end{array}$} & Introducing the lesson & + & + & + & + \\
\hline & Giving students to groups & + & - & - & + \\
\hline & Assigning instructions & + & + & + & - \\
\hline & Checking understanding of Instructions & + & + & + & + \\
\hline & Arranging students' seats & - & + & ++ & - \\
\hline & Briefing group leaders & + & - & - & + \\
\hline & Assigning roles to students & + & - & -- & - \\
\hline & Allotting enough time & - & - & + & - \\
\hline
\end{tabular}

\footnotetext{
+ =seen (observed), - = note seen (not observed), T1 = Teacher One, T2= Teacher Two, T3 = Teacher Three, and T4 = Teacher Four
}

\section{Monitoring Group Performances}

As discussed above, effective group performance entirely depends on the teacher's monitoring role. During this process, teachers should provide assistance when asked by moving round the class with the objective of students' genuine interaction. With regard to monitoring group performance, Callahan and Clark (1988:160) express their concern of how the teacher should monitor group interaction as "monitoring requires constant checking and feedback". Thus, the roles of the EFL teacher as group task begins to work become going from group to group, assigning how well they are performing and helping students who are having difficulty targeting improving their target language.

As stated earlier, the main objective of this study was to find out how teachers treat group performances and provide feedback in EFL classrooms at secondary school level. Under this big category of teachers monitoring learners' group activity: teachers' movement in the classroom, managing tasks, interviewing skills, and providing help are presented by the summary of the observed FEL teachers' monitoring skills of group performances that the research adapted and used as the classroom observation checklist.

\section{Movement in the Classroom}

The descriptions of table 4 reflect that while the students were discussing in groups, almost all of the teachers were moving in the classrooms. However, as indicated in the descriptions, T1 moved in the classrooms to help only the active students and those who were voluntary to raise their hands to ask and answer questions. In the group discussion, some teachers were moving in the classroom whispering to learners' ears saying 'speak in English', but did not equally treat the students as the backbenchers showed little interest and engagement in the task. Besides, as shown in the above 


\section{Zeleke Teshome Lucha}

observation checklist, moving here and there in the classroom, for instance, T3 used to say, 'good participation' but he gave attention only for two groups where there were clever students. Nevertheless, T4 was mostly standing infront of the class and did not move around the classroom to inspect students' performances after giving group activity. However, as shown in the responses of the teacher-participants, they claim moving from one group to another and helping their students. The following extracts from T1 and T3 are their responses for the question of monitoring group performances.

T1 said: "I move from one group to another and tell them not to be shy. I tell them to interact with each other. I listen to their discussion and help them, but I never interrupt them".

For the same question, T3 responded that "I supervise them and monitor the activity in what ways they are discussing, whether the students are exchanging the activity or not. And also monitor their medium of instruction".

However, as expressed by some other teachers during the interviews, they only inform the students what they do in the classroom and as the interaction among the students would also move smoothly and cooperatively.
Sci. Technol. Arts Res. J., Jan-March 2015, 4(1): 187-196

Student-respondents have given the following responses during the focused group interview (FGI) regarding teachers' monitoring group performances:

- Some teachers rarely monitor students' group performance, others simply move here and there and still others just stand infront of the class $(S 2, S 3, S 5$, S6, \& S8).

- Teachers give responsibility only to group leaders and as a result they do not follow up other learners' group performance (S1, S3, S4, S6 \& S7).

- Some teachers do not help students when they face difficulty while discussing in group (S1, S2, S3, S6, \& S8).

The above data from the descriptions of classroom observations, students' and teachers' interview responses imply the following:

- Some teachers rarely provide help to students moving in the classrooms while others aimlessly move around the classroom. As a result, some students were heard discussing in their mother tongue and others were observed writing on their text book and talking about other personal affairs.

- Most of the students do not get opportunities to practice the target language as the group leaders were dominating the discussion and teachers hardly monitor and provide feedbacks for all groups equally.

Table 4: How Teachers Monitored Group Performances during CR Observation

\begin{tabular}{clllll}
\hline \multirow{2}{*}{ Teacher Roles } & \multicolumn{2}{c}{ Sub-Skills } & \multicolumn{5}{c}{ Teachers } & Observed \\
\cline { 3 - 5 } & & T1 & T2 & T3 & T4 \\
\hline \multirow{3}{*}{ Moving in to group } & Moving in the classroom & + & + & + & + \\
& Managing tasks & + & - & & + \\
& Interviewing & - & - & - & - \\
& Providing help & - & - & - & + \\
\hline
\end{tabular}

+ =seen (observed), $-=$ not seen (not observed), T1=Teacher One, T2= Teacher Two, T3=Teacher Three, And T4 =Teacher Four

\section{Managing Tasks}

As indicated in table above, the CR observation result shows that there was no turn taking among students as almost all teachers did not monitor group performances well. It is also described that teachers run only with the pace of a few clever students and others could not get chances to practice the target language. Besides, it was observed during $\mathrm{CR}$ observations that while teachers were talking with group leaders, others were talking about their personal dealings in their mother tongue (Oromo language) in English classrooms.

The results in students' interview indicate that teachers tend to explain everything by themselves than distributing tasks for learners and sometimes jump over activities that clearly seek group performances. Besides, studentrespondents have responded that some of their teachers give the group tasks in the assignment form than dealing in the classroom. Even teachers give little attention for the groups that do not show lively participation and give emphasis for the groups which accomplish their tasks early.

It is shown in responses given during teachers interview, however, that they manage group tasks by distributing activities and by telling their students difficult words. One of the respondent -teachers forwarded that:

I go round and ask them if there is any question. Sometimes, they become-what -lack of vocabulary.
They know it in their own language....in their own language. They ask me, for example, let me say in Oromiffa" marqaan maal jechuudha? -they say. Then I have to help them in English. This means directly I tell them the word and the point. After that going round I check their problem (T1).

The findings from these two instruments indicate that teachers rarely distribute group activities which led to some students shift to their mother tongue. This shows that teachers have little contribution to present tasks, which fit to the students' level. With respect to intervention, it is summarized in the above table that all teachers have interrupted students while they were discussing. This was detected during lesson observation that they interrupted students' discussion for further explanation, to ask answers for some questions, and to tell students to use only English and so on.

Most of the time, when teachers monitor group performances, they may come across students who face difficulty where his/ her intervention is mandatory. Robertson (1990:199) suggests that teachers may consider intervening in the following instances:

- To check for understanding,

- To ask questions that will help the group performance more effectively,

- To clarify directions for the whole class, and

- To give specific feedback to the group about their performances. 


\section{Moving Out of Group Work Activity}

This is the stage where English teachers end group activity by calling every students' attention for feedback. The table below presents the summary of how English teachers managed feedback provision at the end of the students' group performances during the CR observation sessions.

\section{Providing Closure}

At this moment, teachers should end the group performance by asking the group that can model the class to present what has been done while other groups or students are performing the group tasks. Ur (1996:234) suggests that "---the teacher should finish the activity while the students are still enjoying it and interested or only just beginning to flag". The teacher should have the time- budget for this.
The data in the table 5 indicates that all the observed teachers have provided closure for group activities by asking the group leaders to report what they have discussed or written. As witnessed during CR observation, only those students who dominated the group discussion presented the final reports from few groups. As approved by the responses of teachers during the interview, at the end of group discussion some of them encourage their students (the group leaders) to present their report. For example, the following extract from T3 interview responses reveals how he ends the whole-class and the sample group report to the class talking on what they have discussed. "At the end, I say something about the general or whole topic" (T3). On the other hand, another half of the interviewed teachers, were asked how they end group discussion, and replied that they give orders and advice for the group leaders to report.

Table 5: How Teachers Moved Out of Group Performances During CR Observation

\begin{tabular}{clllll}
\hline \multirow{2}{*}{ Teacher Roles } & \multicolumn{1}{c}{ Sub-skills } & \multicolumn{2}{c}{ Teachers observed } \\
\cline { 2 - 5 } & & T1 & T2 & T3 & T4 \\
\hline \multirow{2}{*}{ Moving in to group activity } & Winding group performances & + & + & + & + \\
& Signaling for every one's attention & - & - & - & - \\
& Managing feedback & - & - & + & - \\
\hline \multirow{2}{*}{$+=$ =seen (observed), -=not seen (not observed), T1= Teacher One, T2= Teacher Two T3 =Teacher Three, And T4 =Teacher Four. }
\end{tabular}

The responses given during students' interview, however, show that teachers proceed to closure only with the pace of few bright students, group leaders, and with students who accomplish their tasks earlier. The following extracts are accents from the students' focus group interview (FGI):

If there are group leaders for each group, the teacher asks them to report what they have written. They read it from their exercise book or a piece of paper. I mean this is done at the end of the class. After the report of the voluntary group leaders, the teacher repeats what they have said and leaves the class. He gives us the summary by reading from his guide. I mean he reads and we listen to it. At the end, our teacher goes around the group of the clever students and asks one student to report (S3, S5, S6, S7 \& S8).

The sum of the results found from the CR observation and both teachers' and students' interviews shows that teachers lack the experience of monitoring group performances and providing feedbacks equal for group members by giving equal attention. It also indicates that the EFL teachers assign the same students every time for report. Because of this, students' turn taking is minimal. However, as most of the review of related literature reveal, the main purpose of providing closure is to provide the students a model, which consolidates what they discussed earlier.

\section{Providing/ Managing Feedback}

Feedback is the information to be given to the students about their group performances. The above table that is the result of the CR observation depicts that almost all teachers gave little attention to feedback provision in terms of language and content after students' group discussion. The descriptions showed that teachers give emphasis to treating answer from the textbook, advising students and repeating the reports of group leaders in a state of providing feedback. Besides, teachers were reported giving heavy stress to students' grammatical errors, whenever they provide feedback, which was given only for student-reporters. Others would not get this opportunity.

It is also shown in the responses given during students' interviews that teachers don't provide feedback on the strengths and /or weakness of group performances in the context of full class. With regards to teachers' feedback provision after group discussion, teachers' responses in the interview indicate that they provide and manage feed back in different ways. Participant teacher has a say with regards to this as: "I really appreciate their work. I say, good, nice discussion, do not stop your discussion even if you have language problem. At the end, I summarize the topic" (T1). But T1 did not explicitly put how he manages the feedback and what area does his feedback covers. Another teacher responded that "I follow up when they discuss and give my suggestion at the end" (T2).

As found from these two instruments, teachers rarely provide students the opportunity to give feedback to each other. Moreover, little attention is given to inappropriate students' responses, or report (i.e. content) and language with the objective of improving the groups' performances. In the review literature, however, it is shown that the group task and the linguistic performance of the learners should go together. Ur (1996:234) disclosed that a feedback session should take place in the context of all students' participation in which both teachers and students get the opportunity of communicating what has been done. This must be done with the objective of improving learners' target language use.

\section{Problems Students Encounter in Language Classrooms in Using Group Performances and How Teachers Manage Them}

As regards to the problem with group performances and how EFL teachers manage it, the researcher obtained reliable data during the $\mathrm{CR}$ observation sessions and students interviews. Concerning what problems teachers face in monitoring group performances, students' group practices and how teachers handle feedback provision, 


\section{Zeleke Teshome Lucha}

students-respondents have given the following responses during their interviews:

- They discuss in Oromo language because they can't express their ideas in English and for fear of each other to discuss using the target language -English.

- Many students are reserved for fear of making mistakes. They say that their colleague will laugh at them if they commit mistakes during group discussion.

- Some say their teachers lack experience of guiding them how to do the given group activities and do not give them responsibilities. As a result, they lose interest to learn the target language cooperatively.

- Some teachers either simply stand infront of the class or sit on the table and others aimlessly wander around the classroom.

- Almost all the students say group leaders and /or active students dominate the discussion. Consequently, others talk about their personal affairs.

- Teachers do not provide related feedback for students after group performances.

- They say most teachers do not consider group performances as a serious task. Therefore, students do not give attention for group work too.

- Some students raised that there are large numbers of students in a class. As a result, teachers can't monitor their group performance.

- Teachers want to cover two different and big lessons within 40 minutes. So, they don't give enough time for students' group discussion.

Furthermore, during teachers' interview, one of the teachers has responded as follows: "Yes, I faced some problems. For example, students' sitting arrangement is not feasible for group work activities. As well the students' in one class are crowded. When I move, I mean I can't move students from one place to another" (T1).

For the same case, another teacher said:

Well, something has come to my mind that while I was conducting this group work and / or pair work, sometimes there might be an interference of this vernacular language. Therefore, while I was visiting them, they were speaking their mother tongue. This is the serious problem I observed (T2).

As a remedy, T2 has advised them not to use their mother tongue and has told them the values of practicing using the target language -English.

Similarly T3 also said:

Some of the problems are when they discuss in groups there is domination. Some students dominate others. Especially, ladies can simply listen to other students and their participation is not more. Therefore, I see certain domination of some students.

To overcome the problem, EFL teacher should well monitor the students in supporting them to be able to discuss about a certain topic, than discussing about certain other issues and what they have outside the classroom. The interviewed teachers have suggested that students should be given plenary discussion, well managed, and the number of students in one class should be small enough for group work to alleviate the problems.
Sci. Technol. Arts Res. J., Jan-March 2015, 4(1): 187-196

From the sum of the results found from students' and teachers' interview responses, the following common problems were identified. They include:

- Students' use of their native language during group performances ,

- Teachers' poor classroom management,

- A few students' domination of other group members,

- Large number of students in a class,

- Teachers' lack of experience in monitoring students' group performances and not considering group work as a serious task.

As a result of these, teachers claim that it is problematic to monitor group performances in the EFL classes. It should be noted that the above problems should not discourage EFL teachers from making effort for the success of group performances.

\section{CONCLUSIONS}

The study indicated that one factor which may have affected students' involvement in group performances was not their understanding procedures, routine and responsibilities at the beginning. Teachers' group formation is not enough by itself unless students know what is expected of them. Thus, not giving clear instruction has been observed as a problem. Only assigning students to groups do not guarantee all of them to be involved in to the discussion. Giving emphasis only to group leaders and teachers taking a great deal of students' time inhibits them from taking part in group discussion.

Though all students gain equally from working in groups, it was found only the outstanding students/group leaders were given roles and benefiting from it. It was found out that students usually discuss in Oromo language and sometimes talk about their own issues during group discussion. This indicates that teachers' group task monitoring skill is not strong. Though teachers claim that they make use of group performance one teaching approach, their monitoring of learners' group performance is weak. Some teachers jump over group activities, interrupt students while discussing pointless and rarely distribute group activities. There is no student assignment to groups on the basis of their interest and ability.

The data yield from the CR observation and students' interviews have generated several useful information. One of the findings is that some teachers do not follow up learners' group performance though move around the classroom; others merely stand infront of the class. After group work, teachers provide advice for students and offer feedback only on grammatical errors. However, there is no well grounded comment or feedback on the strengths and /or content of their discussion or the tasks under discussion in the context of full class. Besides, teachers give little attention for learners to comment each other.

Thus, conducting students' group performances and exerting an endeavor to handle for its success is great challenge for EFL teachers. Students at high school level need to be provided with opportunities to practice the target language by negotiating meaning with one another in small groups. In learner-centered classroom, the teacher remains entirely responsible for ensuring that effective learning takes place. Identifying areas of 


\section{Zeleke Teshome Lucha}

responsibility to transfer to learners would be a central aspect of the teacher's role. But from the findings of this study not much is done in this regard. As result, teachers at this level should make proper considerations of monitoring group work appropriately in English classes by raising students' awareness of why they are using group performance and its communicative goals.

Therefore, efforts must be made to prepare teachers to be able to have the knowledge of treating students' group performance in the EFL classroom. To this end, the English language improvement Program (ELIP) that has recently been given for teachers should be strengthened in the future to equip them with teaching techniques of conducting and monitoring group work with the objective of students' language practices.

\section{Conflict of Interest}

Conflict of interest none declared.

\section{REFERENCES}

Amends, R. (1997). Classroom instruction and management. New York: the McGraw-hill comnines, Inc.

Barnes, D. (1973). From communication to curriculum. Middle sex, England: Penguin Books.

Biota, C. and Ease, P. (1994). Collaborative staffs and classroom. London: David Fulton Publishers.

Borich, D. (1998). Effective teaching methods. New York: Macmillan.

Brumfit, C. (1984). Teaching communication methodology in language. Cambridge: Cambridge University Press.

Burges, G.R. (1983). Strategy of education research: qualitative methods. London: the Flamer Press.

Byrne, D. (1987). Teaching oral English (new edition). London: Longman Group UK Ltd.

Callahan, J. and Clark, L. (1988). Teaching in the middle and secondary schools. New York: Macmillan Publishing Company.

Christison, M.A. (1990). Cooperative learning in the EFL classroom. In kraal Thomas (end) elected articles from English Teaching Forum 1989-1993.

Gower, R., Philips, D. and Walters, S. (1995). Teaching practice handbook reference book for EFL teachers in training. London: Heinemann Educational books Ltd.

Hadfield, J. (1992). Classroom dynamic. Oxford: Oxford University Press.

Harmer, J. (1983). The practice of English language teaching. London: Longman.
Sci. Technol. Arts Res. J., Jan-March 2015, 4(1): 187-196

Harmer, J. (1991). The practice of English language teaching. Hallow: Longman.

Hayes, D. (1997). Helping teachers to cope with large classes. EFL Journal 51(2): 106.

Hill, D. (1995). Pair work and group work. In: English Teaching Professionals, Issue 34 September 2004.

Johnson, K. and Johnson, R. (1976). Learning together and alone. Englewood cliffs: NJ Prentice Hall.

Johnson, K. and Johnson, R. (1990). http://etd.Rau. Acza//these/available/end.

Lewis, M. and Hill, J. (1987). Practical techniques for language teaching guideline. Ford: Biddy Ltd.

Littlewood, W.T. (1975). Group work and communicative competence in the ESL classroom. TESOL 75: 233. Washington DC.

Moore, K. (1995). Classroom teaching skills. New York: McGraw Hill, Inc.

Murdoch, G.S. (1990). Practicing what we preach. A trainee-centered approach in service training. In Forum 28(4): 15-18.

Nolasco, R and Arthur, L. (1986). Trying doing it with a class of forty. ELT Journal 402: 100-106.

Norman. D, Levin. U. and Hedenquist, J. (1986). Communicative ideas: an approach with classroom activities. London: Language Teaching Publications.

Nunan, D. (1991). Language teaching methodology. London: London Prentice-hall.

Nunan, D. and Lamb, C. (1996). The self-directed teacher. Cambridge: Cambridge University Press.

Screener, J. (1994). Learning teaching, a guidebook for English language teachers: Oxford: Macmillan Publishers Limited.

Tudor, I. (1993). Teacher roles in the learner- centered classroom. EFL Journal 47(I):22-31.

Tudor, I. (1996). Learner -centeredness as language teaching: practice and theory. Cambridge: Cambridge University Press.

Ur, P. (1996). A course in language teaching: practice and theory. Cambridge: Cambridge University Press.

Wheeler, J. (1994). http://www.sa.zburgseminar/org/assc/ csacl/progs/ interactive/rajka.html.

Wright, T. (1987). The roles of teachers and learners. Oxford: Oxford University Press. 